\title{
Assessment of soil carbon dioxide efflux and its controlling factors in moist temperate forest of West Himalayas
}

\author{
Parmanand Kumar*, Ranjeet Singh, Hukum Singh, Tara Chand and N. Bala \\ Forest Ecology and Climate Change Division, Forest Research Institute, Dehradun 248 006, India
}

In this study, the soil $\mathrm{CO}_{2}$ efflux was measured by closed dynamic system method along with soil and meteorological parameters at 1600,1700 and $1800 \mathrm{~m}$ elevations along different directional-aspects over a period of one year. The annual $\mathrm{CO}_{2}$ efflux rate $\left(F_{\mathrm{c}}\right)$ varied from 1.02 to $22.57 \mu \mathrm{mol} \mathrm{m}^{-2} \mathrm{sec}^{-1}$, which was highest in the rainy season. The annual average $F_{\mathrm{c}}$ was maximum $\left(8.67 \mu \mathrm{mol} \mathrm{m} \mathrm{mec}^{-1}\right)$ at east facing slope followed by 7.58 and $7.32 \mu \mathrm{mol} \mathrm{m}^{-2} \mathrm{sec}^{-1}$ at south facing slope and north facing slope respectively. Temperature $\left(T_{\mathrm{s}}\right)$, moisture $\left(S_{\mathrm{m}}\right)$ and evaporation of soil were found to be significant variables and selected to develop the regression model with $R^{2}$ value of 0.85 . The effect of soil moisture on $F_{\mathrm{c}}$ above $15^{\circ} \mathrm{C} T_{\mathrm{s}}$ exhibited a better relationship with $R^{2}$ value of 0.48 and temperature sensitivity (Q10) was found 3.25. This study reveals that the key controlling factors of $\mathrm{CO}_{2}$ efflux rate are soil moisture and soil temperature, which explains $66 \%$ variation in soil $\mathrm{CO}_{2}$ efflux.

Keywords: Seasonal variation, soil $\mathrm{CO}_{2}$ efflux, soil moisture, soil temperature, spatial variation, west Himalayas.

SoIL is the largest terrestrial pool of stored carbon with over $1500 \mathrm{Pg}$, which is almost twice as much carbon as the vegetation and the atmosphere combined ${ }^{1,2}$. Moreover, soil $\mathrm{CO}_{2}$ efflux is the major connecting link between the biosphere and atmosphere ${ }^{3}$ through which 75-100 Pg carbon releases in the atmosphere every year ${ }^{4}$. Despite the importance of soil carbon pool and carbon cycle, understanding of $\mathrm{CO}_{2}$ emission processes and their sensitivity to changing climatic conditions are unclear ${ }^{5,6}$. The soils of moist temperate forest of West Himalayas have $210.65 \mathrm{Tg}$ organic carbon (OC) stored and continuously increasing temperature due to global warming is making the whole ecosystem vulnerable ${ }^{7,8}$. The soil $\mathrm{CO}_{2}$ efflux has been studied in various forest ecosystems since last four decades $^{9-11}$ and several studies along physiographic gradients have also been conducted ${ }^{12,13}$.

\footnotetext{
*For correspondence. (e-mail: parmanand30@gmail.com)
}

Nevertheless, soil $\mathrm{CO}_{2}$ emissions are associated with land use, physiography and climatic conditions ${ }^{3}$. Moreover, biochemical processes such as root respiration and organic carbon decomposition are also important factors that determine the rate of soil $\mathrm{CO}_{2}$ emissions ${ }^{14}$. In addition, species composition, age of forest and management practices also affect this emission ${ }^{15,16}$. Besides, all the associated factors that determine the soil $\mathrm{CO}_{2}$ efflux rate $\left(F_{\mathrm{c}}\right)$ change over time and space ${ }^{17}$. Therefore, the assessment of soil $\mathrm{CO}_{2}$ emissions and their associated biotic and abiotic factors are important to estimate the potential impact of environmental changes on soil carbon storage in the Himalayan ecosystem. Of all the factors that affect soil $\mathrm{CO}_{2}$ emissions, soil temperature, soil moisture, plant carbon input and soil organic carbon are the most significant factors $^{10,18}$. The soil temperature has an influence on litter decomposition and root respiration whereas soil moisture affects the microbial community by influencing substrate availability and oxygen exchange in soil ${ }^{19,20}$. The $F_{\mathrm{c}}$ varies with environmental conditions as reported in different ecosystems. Many studies have been done to quantify $F_{\mathrm{c}}$ and to understand the impact of environmental variables on $i^{21,22}$. Although the relationship of soil temperature and soil moisture with soil $\mathrm{CO}_{2}$ emission has been studied separately in many studies across ecosystems $^{23}$, the impact of soil temperature in conjunction with soil moisture is not well understood in Himalayan forest ecosystems. Many studies reported that the soil $\mathrm{CO}_{2}$ efflux will change with changing climatic conditions ${ }^{24,25}$, although the direction and extent are not clear. Moreover, soil temperature and soil moisture are the most important factors of soil $\mathrm{CO}_{2}$ emissions. However, elevation and directional-aspect also affect the soil properties and micro-climatic factors and are responsible for the emissions. The main objective of the present study was to assess the soil $\mathrm{CO}_{2}$ efflux rate and its controlling factors in the moist temperate forest of Uttarakhand, West Himalayas. Furthermore, various micro-climatic parameters, i.e. soil temperature, air temperature, soil moisture, relative humidity, evaporation rate, and wind speed to be used for development of linear model, can be used for prediction of soil $\mathrm{CO}_{2}$ efflux rate and for the experimental environment similar to that of the reported study region. 


\section{Materials and methods}

\section{Study area}

Himalayan moist temperate forests cover about $30,165.83 \mathrm{sq} . \mathrm{km}$ area of India which is about $0.92 \%$ of the total geographical area ${ }^{26}$. The study was conducted in the natural evergreen forest of Kempty watershed, Mussoorie which lies between $30^{\circ} 27^{\prime}-30^{\circ} 29^{\prime} \mathrm{N}$ lat. and $78^{\circ} 00^{\prime} \mathrm{E}-78^{\circ} 02^{\prime} \mathrm{E}$ long. on the outermost ridge of the Himalayas in west-east direction. The micro-watershed having about 290.33 ha catchment area with elevation varying from $1650 \mathrm{~m}$ to $2000 \mathrm{~m}$ amsl and topography of the study area is undulating. For this study we stratified the elevation range into $1700 \mathrm{~m}, 1800 \mathrm{~m}$ and $1900 \mathrm{~m}$ amsl. The principle rock here is limestone and gypsum mineral is present in abundant quantities. The soil order is inceptisol and texture is sandy loam but its composition, depth, moisture, and humus content vary considerably depending on the aspect, slope and soil cover. Vegetation of the study area is banj oak mixed forest and major tree species are Quercus leucotrichophora (Banj oak), Daphniphyllum himalayense (Ratnali), Machilusod oratissima (Kaul), Toona serrata (Darli) and Rhododendron arboretum (Burans). The shrub species are Hypericum oblongifolium (Phiunli), Zanthoxylum alatum (Timru), Coriaria nepalensis (Masura/Mansuri), Pyracantha crenulata (Ghingaru), etc. and the herbaceous plants include Thalictrum foliolosum (Mimari), Reinwardtia indica (Basant), Oxalis spp. (Tirpatia) and Fragaria indica (Wild strawberry).

\section{Site selection}

The study was undertaken in five sampling points and these were selected on the basis of physiography, i.e. elevation, slope and aspect (Figure 1). Moreover, sampling points were selected at three different elevations, i.e. $1700 \mathrm{~m}, 1800 \mathrm{~m}$ and $1900 \mathrm{~m}$ amsl. Out of the five sampling points, three sampling points were selected at $1800 \mathrm{~m}$ elevation along with different directional-aspects (south, east and north-facing), whereas one sampling point each was selected at $1700 \mathrm{~m}$ and $1900 \mathrm{~m}$ elevation respectively.

\section{Meteorological data}

The weather parameters were recorded by the meteorological station established in the study area. Climatically, the area is predominantly temperate receiving annual rainfall of $2000-2500 \mathrm{~mm}$. A major share $(85 \%)$ of rainfall is received during southwest monsoon from June to September. The mean annual temperature varies from $11^{\circ} \mathrm{C}$ to $16^{\circ} \mathrm{C}$ and monthly mean temperature varies from $3^{\circ} \mathrm{C}$ to $5^{\circ} \mathrm{C}$ during December-January to $20^{\circ} \mathrm{C}$ to $22^{\circ} \mathrm{C}$ in May-June respectively.

\section{Soil analysis}

Soil samples from $0-15 \mathrm{~cm}$ and $15-30 \mathrm{~cm}$ depths were collected from each sampling point (Figure 1) and soil physico-chemical properties, i.e. $\mathrm{pH}$, texture, bulk density (BD), OC, nitrogen, phosphorus and potassium were analysed to assess the soil health and nutrient status (Table 1). Moreover, the litter samples were collected from $1 \mathrm{~m} \times 1 \mathrm{~m}$ quadrates by monthly basis and ovendried at $72^{\circ} \mathrm{C}$ for $96 \mathrm{~h}$ to obtain constant moisture content. Litter carbon content was calculated as $50 \%$ of the dry biomass which was considered as total carbon addition to the soil ${ }^{27}$.

\section{Soil $\mathrm{CO}_{2}$ efflux measurement in forest ecosystem}

The soil $\mathrm{CO}_{2}$ efflux rate $\left(F_{\mathrm{c}}\right)$ was measured using closed dynamic system method ${ }^{28}$. Under this method, a closed chamber of PVC sheet with dimensions $0.2 \mathrm{~m} \times 0.2 \mathrm{~m} \times$ $0.2 \mathrm{~m}$ was used to monitor the $\mathrm{CO}_{2}$ emission and it was connected to the console of portable photosynthesis system (LICOR, Inc. USA). The chamber was placed on the soil surface after removing litter and fixed properly to avoid leakage. The $F_{\mathrm{c}}$ was monitored for $3 \mathrm{~min}$ and repeated three readings were recorded at each sampling point. The $F_{\mathrm{c}}$ was measured between $9: 00$ am and 12:00 noon and was considered as the representative of mean flux rate of a day ${ }^{10}$. The $F_{\mathrm{c}}$ was calculated using the following equation ${ }^{29}$.

$$
F_{\mathrm{c}}=\frac{P V}{\mathrm{RTS}} \times \frac{\mathrm{d} C}{\mathrm{~d} t},
$$

where $P$ is the pressure, $V$ the chamber volume, $R$ the gas constant, $T$ the temperature, $S$ the soil surface area covered by the chamber and $\mathrm{d} C / \mathrm{d} t$ is the change in $\mathrm{CO}_{2}$ gas concentration in chamber with time.

The soil temperature $\left(T_{\mathrm{s}}\right)$ was measured at $0-10 \mathrm{~cm}$ depth by using soil thermometer, and soil moisture $\left(S_{\mathrm{m}}\right)$ for the depth of 0-30 $\mathrm{cm}$ was measured by the gravimetric method. Other micro-climatic variables such as monthly evaporation, wind speed and relative humidity data were collected from the meteorological observatory established at the study area.

\section{Soil $\mathrm{CO}_{2}$ efflux models}

In order to identify the factors affecting $F_{c}$, predictive statistical analysis was performed. The meteorological parameters, i.e. soil and air temperature, soil moisture, relative humidity, evaporation rate and wind speed were correlated with $F_{\mathrm{c}}$ to understand the relationship. A 


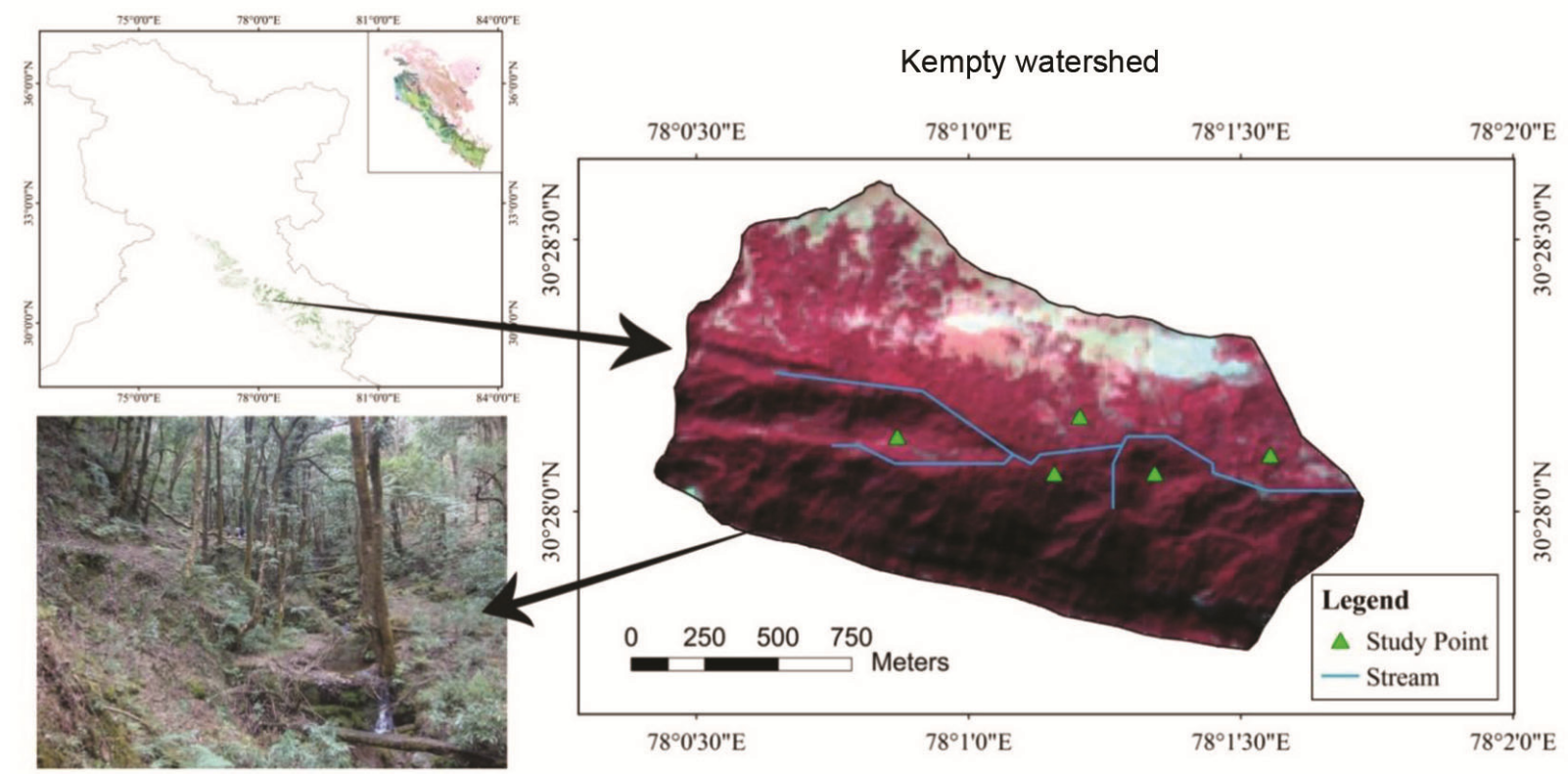

Figure 1. Location of study area and map of moist temperate forest of West Himalaya ${ }^{26}$.

Table 1. Physico-chemical properties of soil from different depth and altitudinal gradient

\begin{tabular}{|c|c|c|c|c|c|c|}
\hline \multirow{2}{*}{$\begin{array}{l}\text { Elevation (m amsl) } \\
\text { Soil depth }\end{array}$} & \multicolumn{2}{|c|}{$1700 \mathrm{~m}$} & \multicolumn{2}{|c|}{$1800 \mathrm{~m}$} & \multicolumn{2}{|c|}{$1900 \mathrm{~m}$} \\
\hline & $0-15 \mathrm{~cm}$ & $15-30 \mathrm{~cm}$ & $0-15 \mathrm{~cm}$ & $15-30 \mathrm{~cm}$ & $0-15 \mathrm{~cm}$ & $15-30 \mathrm{~cm}$ \\
\hline $\mathrm{pH}$ & 07.70 & 07.95 & 07.50 & 07.68 & 07.70 & 07.75 \\
\hline Sand & 67.10 & 66.02 & 58.15 & 59.13 & 64.08 & 58.16 \\
\hline Silt & 10.06 & 09.14 & 28.01 & 27.03 & 30.08 & 35.00 \\
\hline Clay & 22.84 & 24.84 & 13.84 & 13.84 & 05.84 & 06.80 \\
\hline $\mathrm{BD}\left(\mathrm{g} \mathrm{cm}^{-3}\right)$ & 01.59 & 01.13 & 01.10 & 01.19 & 01.02 & 01.29 \\
\hline OC $(\%)$ & 07.73 & 05.89 & 05.81 & 04.94 & 03.80 & 01.82 \\
\hline $\mathrm{N}\left(\mathrm{kg} \mathrm{ha}^{-1}\right)$ & 1344.0 & 1590.4 & 1142.4 & 963.2 & 1075.2 & 672.0 \\
\hline $\mathrm{P}\left(\mathrm{kg} \mathrm{ha}^{-1}\right)$ & 19.04 & 14.56 & 23.52 & 25.76 & 16.80 & 19.04 \\
\hline $\mathrm{K}\left(\mathrm{kg} \mathrm{ha}^{-1}\right)$ & 313.60 & 291.20 & 358.40 & 313.60 & 134.40 & 156.80 \\
\hline
\end{tabular}

regression model was developed for $F_{\mathrm{c}}$ by using meteorological parameter with the help of stepwise forward selection method. Furthermore, the relationship between $F_{\mathrm{c}}$ and soil temperature was established, and linear, exponential and temperature sensitivity $\left(Q_{10}\right)$ regression models were developed as follows

$$
\begin{aligned}
& F_{\mathrm{c}}=a \times T_{\mathrm{s}}+b, \\
& F_{\mathrm{c}}=a \times \mathrm{e}^{(b \times T \mathrm{~s})}, \\
& F_{\mathrm{c}}=R_{10} \times Q_{10}(T \mathrm{~s}-10) / 10 .
\end{aligned}
$$

Linear and quadratic model was developed by using soil moisture as a variable

$$
\begin{aligned}
& F_{\mathrm{c}}=a \times S_{\mathrm{m}}+b, \\
& F_{\mathrm{c}}=a \times S_{\mathrm{m}}+b \times S_{\mathrm{m}}^{2}+c .
\end{aligned}
$$

The combined effect of soil temperature and soil moisture on $F_{\mathrm{c}}$ was established as follows

$$
\begin{aligned}
& F_{\mathrm{c}}=a \times T_{\mathrm{s}}+b \times S_{\mathrm{m}}+c, \\
& F_{\mathrm{c}}=\left(R_{10} \times Q_{10}{ }^{(T \mathrm{~s}-10) / 10}\right) \times\left(a \times S_{\mathrm{m}}+b \times S_{\mathrm{m}}^{2}+c\right),
\end{aligned}
$$

where $F_{\mathrm{c}}$ is the measured soil $\mathrm{CO}_{2}$ efflux rate $\left(\mu \mathrm{mol} \mathrm{m}{ }^{-2}\right.$ $\left.\mathrm{sec}^{-1}\right), T_{\mathrm{s}}$ the soil temperature at $10 \mathrm{~cm}$ depth, $S_{\mathrm{m}}$ the soil moisture content at $0-30 \mathrm{~cm}$ depth, and $R_{10}, Q_{10}, a, b, c$ are the fitted parameters. Furthermore, $Q_{10}$ is the temperature sensitivity factor of soil $\mathrm{CO}_{2}$ efflux which represents the change in $\mathrm{CO}_{2}$ efflux rate with $10^{\circ} \mathrm{C}$ rise in temperature, and $R_{10}$ represents fitted soil $\mathrm{CO}_{2}$ efflux at $10^{\circ} \mathrm{C}$.

$$
Q_{10}=\left(R^{2} / R_{1}\right)^{\left(10 / T_{2}-T_{1}\right)},
$$

where $R_{1}$ and $R_{2}$ are soil $\mathrm{CO}_{2}$ efflux rates at $T_{1}$ and $T_{2}$ temperature respectively. The temperature sensitivity 
function $\left(Q_{10}\right)$ was used for annual soil $\mathrm{CO}_{2}$ efflux rate in different ecosystems ${ }^{22,30}$.

\section{Statistical analysis}

The stepwise linear regression was performed using $R$ package $^{31}$ and the measured soil $\mathrm{CO}_{2}$ efflux rates were applied to the eqs (2)-(8) using least square regression in $R$ language. The best model was selected based on $R^{2}$ and AIC (Akaike's information criterion) criteria.

$$
\mathrm{AIC}=n \times \log \left(\sigma^{2}\right)+2 \times K,
$$

where $\sigma^{2}=($ residual sum of squares $) / n, n$ the sample size and $K$ is the number of estimated parameter where variance was also counted as an estimated parameter ${ }^{32}$.

\section{Results}

\section{Soil properties}

The soil of study area was sandy loam to sandy clay loam in texture and slightly basic in nature having $\mathrm{pH}$ range from 7.5 to 7.95 . The $\mathrm{BD}$ of soil varied from 1.02 to $1.59 \mathrm{~g} \mathrm{~cm}^{-3}$ at different elevations. The OC content was high in upper layer of soil $(0-15 \mathrm{~cm})$ compared to deeper soil $(15-30 \mathrm{~cm})$ and it varied from $1.82 \%$ to $7.73 \%$ indicating high carbon content. OC decreased with increase in elevation and the maximum OC $(7.73 \%)$ was measured at $1700 \mathrm{~m}$ whereas, minimum $(3.8 \%)$ was at $1900 \mathrm{~m}$ elevation for the upper layer of soil. Similar trend was also observed for available nitrogen and it was quite high, ranging from 672 to $1590 \mathrm{~kg} \mathrm{ha}^{-1}$. The maximum nitrogen $\left(1590 \mathrm{~kg} \mathrm{ha}^{-1}\right)$ was measured at $1700 \mathrm{~m}$ whereas, minimum $\left(672 \mathrm{~kg} \mathrm{ha}^{-1}\right)$ was at $1900 \mathrm{~m}$ elevation for the deeper layer of soil. Phosphorus content in the soil varied from 14.56 to $25.76 \mathrm{~kg} \mathrm{ha}^{-1}$ whereas, potassium content varied from 134.4 to $358.4 \mathrm{~kg} \mathrm{ha}^{-1}$ (Table 1). Furthermore, the results showed that the elevation level of $1800 \mathrm{~m}$ was richer in terms of phosphorus and potassium availability than the other two elevation levels.

\section{Total carbon addition in the soil}

The total biomass in the form of litterfall and total carbon addition in the soil during the study period is shown in Figure 2. Litterfall was more in two seasons, i.e. spring (March-April) and autumn (October-November) due to leaf shedding of $Q$. leucotrichophora (spring) and $D$. himalayanse (autumn) trees at the study site. Between the two seasons, maximum litterfall was received during October and November which added more carbon to the soil system. The average monthly total biomass addition and total carbon addition was $24.39 \mathrm{gm}^{-2}$ and $12.20 \mathrm{gm}^{-2}$ respectively.

\section{Monthly and seasonal trend in soil $\mathrm{CO}_{2}$ efflux rate}

The trend of average monthly soil $\mathrm{CO}_{2}$ efflux rate is presented in Figure 3. The maximum $F_{\mathrm{c}}(17.60 \pm$ $\left.1.68 \mu \mathrm{mol} \mathrm{m}^{-2} \mathrm{sec}^{-1}\right)$ was observed in August while minimum was observed $\left(1.58 \pm 0.20 \mu \mathrm{mol} \mathrm{m} \mathrm{sec}^{-1}\right)$ in December. The results showed that $F_{\mathrm{c}}$ was highest during rainy season followed by summer and winter season.

\section{Spatial variability in soil $\mathrm{CO}_{2}$ efflux rate}

The average annual $\mathrm{CO}_{2}$ efflux measured along elevation showed that maximum $F_{\mathrm{c}}$ was at $1800 \mathrm{~m}$ followed by $1700 \mathrm{~m}$ and $1900 \mathrm{~m}$ amsl, i.e. 7.86, 6.42 and $3.90 \mu \mathrm{mol}$ $\mathrm{m}^{-2} \mathrm{sec}^{-1}$ respectively. In the summer season, $F_{\mathrm{c}}$ was maximum $(5.78 \pm 2.14)$ at lower elevation $(1700 \mathrm{~m})$ whereas, during rainy and winter season, maximum $F_{\mathrm{c}}$ was recorded at $1800 \mathrm{~m}$. The coefficient of variation $(\mathrm{CV})$ for soil $\mathrm{CO}_{2}$ efflux during different seasons along elevation

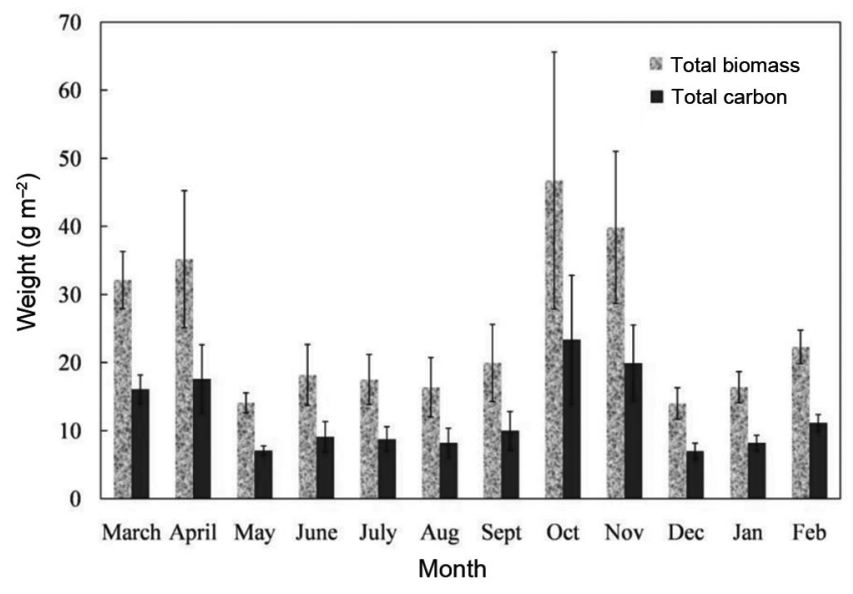

Figure 2. Monthly biomass and carbon additions in forest floor through litterfall (bars represent standard error).

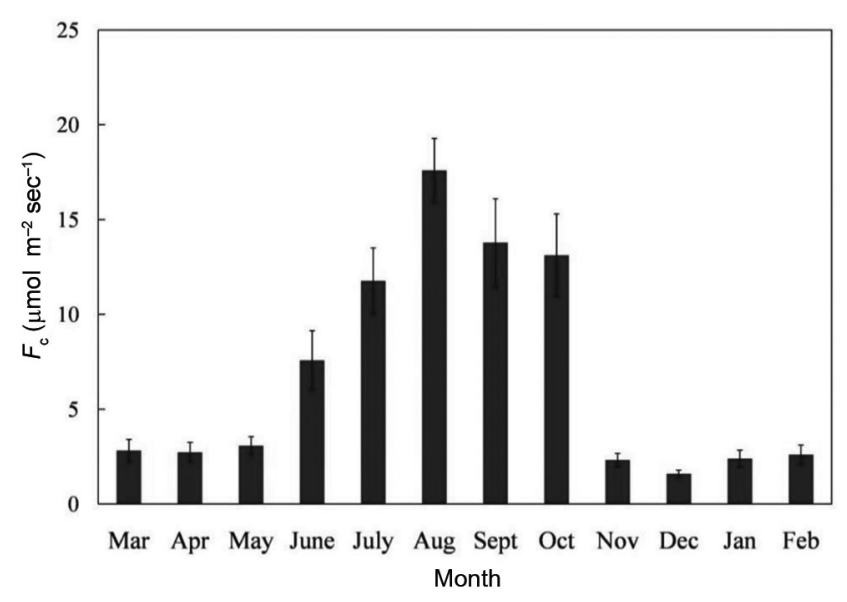

Figure 3. Measured values of average $F_{\mathrm{c}}\left(\mu \mathrm{mol} \mathrm{m} \mathrm{sec}^{-1}\right)$ in different months (bars represent standard error). 
Table 2. Pearson's correlation coefficients between micro-climatic parameters

\begin{tabular}{|c|c|c|c|c|c|c|c|}
\hline & $\begin{array}{l}\text { Soil } \mathrm{CO}_{2} \\
\text { efflux }\end{array}$ & $\begin{array}{c}\text { Soil } \\
\text { temperature }\end{array}$ & $\begin{array}{c}\text { Air } \\
\text { temperature }\end{array}$ & $\begin{array}{c}\text { Soil } \\
\text { moisture }\end{array}$ & $\begin{array}{l}\text { Relative } \\
\text { humidity }\end{array}$ & $\begin{array}{l}\text { Evaporation } \\
\text { rate }\end{array}$ & $\begin{array}{l}\text { Wind } \\
\text { speed }\end{array}$ \\
\hline Soil $\mathrm{CO}_{2}$ efflux & 1.00 & & & & & & \\
\hline Soil temperature & $0.70 *$ & 1.00 & & & & & \\
\hline Air temperature & 0.44 & $0.91 * *$ & 1.00 & & & & \\
\hline Soil moisture & $0.58 *$ & 0.03 & -0.17 & 1.00 & & & \\
\hline Relative humidity & $0.70 *$ & $0.50 *$ & 0.26 & 0.26 & 1.00 & & \\
\hline Evaporation rate & -0.33 & 0.31 & $0.65^{*}$ & $-0.60 *$ & -0.36 & 1.00 & \\
\hline Wind speed & $-0.68 *$ & -0.21 & 0.10 & $-0.63^{*}$ & $-0.71^{*}$ & $0.74 *$ & 1.00 \\
\hline
\end{tabular}

*Significant at 0.05 level; **Significant at 0.01 level.
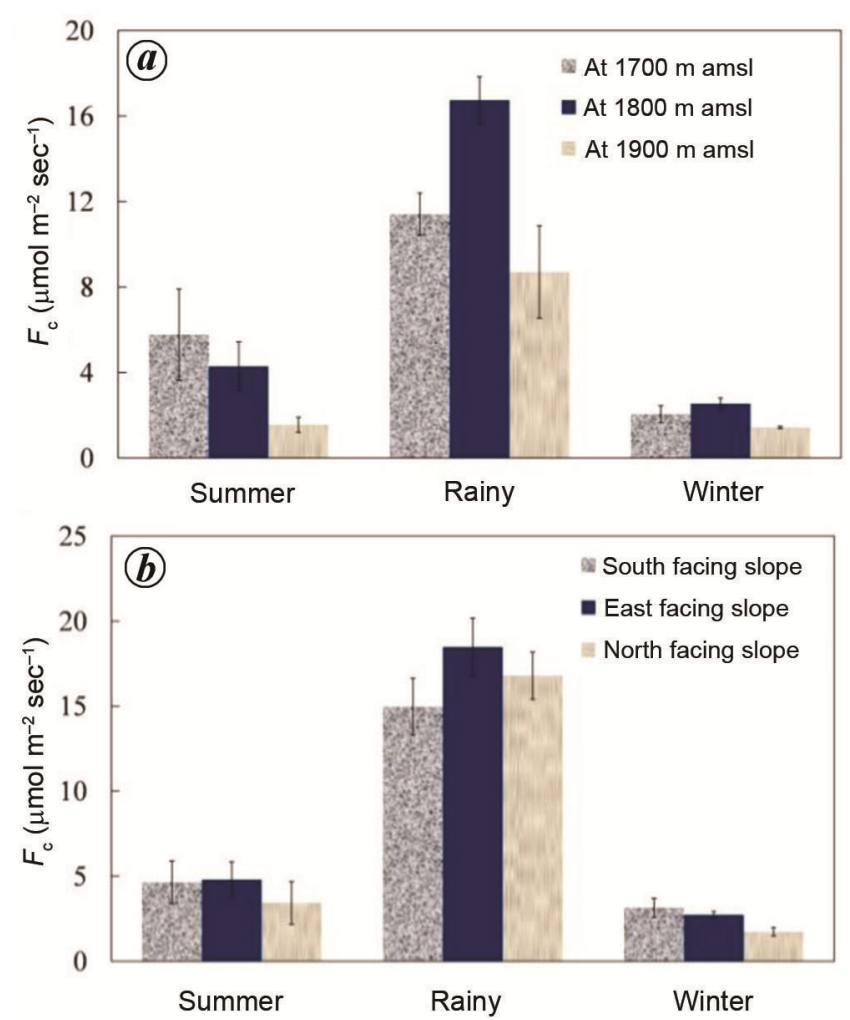

Figure 4. Soil $\mathrm{CO}_{2}$ efflux during different seasons. $\boldsymbol{a}$, Along elevation gradient. $\boldsymbol{b}$, Along directional-aspect (bars represent standard error).

was minimum $(27.62 \%)$ in winter and was maximum $(55.10 \%)$ in summer season (Figure $4 a)$.

The annual average efflux rate measured along different aspects showed that maximum $F_{\mathrm{c}}\left(8.67 \mu \mathrm{mol} \mathrm{m} \mathrm{sec}^{-1}\right)$ was recorded for the east-facing slope whereas, it was $7.58 \mu \mathrm{mol} \mathrm{m}^{-2} \mathrm{sec}^{-1}$ and $7.32 \mu \mathrm{mol} \mathrm{m} \mathrm{sec}^{-1}$ for southand north-facing slopes respectively. During winter season, soil $\mathrm{CO}_{2}$ efflux was maximum $(3.15 \pm 1.11 \mu \mathrm{mol}$ $\left.\mathrm{m}^{-2} \mathrm{sec}^{-1}\right)$ at south-facing slope followed by east-facing $\left(2.73 \pm 0.49 \mu \mathrm{mol} \mathrm{m}^{-2} \mathrm{sec}^{-1}\right)$ and north-facing slope $\left(1.74 \pm 0.42 \mu \mathrm{mol} \mathrm{m}^{-2} \mathrm{sec}^{-1}\right)$ respectively. The $\mathrm{CV}$ for different directional aspects was $10.50 \%$ in rainy season to $28.54 \%$ in winter season (Figure $4 b$ ).

\section{Factors controlling soil $\mathrm{CO}_{2}$ efflux rate}

It was interesting to observe that the monthly average $F_{\mathrm{c}}$ exhibited a significant positive correlation with soil temperature, soil moisture, relative humidity and air temperature, whereas wind speed showed inverse relationship (Table 2). Moreover, these parameters were used to develop linear regression model for estimation of monthly $F_{\mathrm{c}}$ associated with other meteorological parameters by forward stepwise selection method. The $R^{2}$ value of the model was of 0.85 and $P<0.05$ (eq. (11)).

$$
F_{\mathrm{c}}=-13.33+0.95 T_{\mathrm{s}}+0.37 S_{\mathrm{m}}-3.0 E
$$

where $E$ is the evaporation rate.

\section{Temperature and moisture dependent soil $\mathrm{CO}_{2}$ efflux models}

The non-linear least square regression models were developed to assess the impact of soil temperature and soil moisture on $F_{\mathrm{c}}$ independently, and in combination as shown in Table 3 . The variation in soil $\mathrm{CO}_{2}$ efflux due to soil temperature effect was estimated by exponential model with $R^{2}$ of 0.40 and soil moisture effect was expressed by quadratic model with $R^{2}$ of 0.23 . The temperature sensitivity factor $\left(Q_{10}\right)$ was estimated for temperature (eq. (4)) and combined effect (eq. (8)) was found to be 3.25 and 3.37 respectively (Table 3 ). In addition, the combined effect of soil temperature and soil moisture on soil $\mathrm{CO}_{2}$ efflux was established with $R^{2}$ of 0.66 and $P<0.05$ (eq. (8)). Moreover, the combined effect of these parameters was also shown in $3 \mathrm{D}$ plot for linear and non-linear model (Figure 5).

The scatter plot provided here (Figure 6) showed relationship of soil $\mathrm{CO}_{2}$ efflux with soil temperature (Figure $6 a$ ) and soil moisture (Figure $6 b$ ) using exponential and quadratic models respectively. The $F_{\mathrm{c}}$ varied from 1.15 to $4.32 \mu \mathrm{mol} \mathrm{m}^{-2} \mathrm{sec}^{-1}$ (Figure $6 a$ ) for soil temperature below $15^{\circ} \mathrm{C}$, whereas it varied widely between 1.02 and $22.57 \mu \mathrm{mol} \mathrm{m} \mathrm{sec}^{-1}$ for soil temperature above $15^{\circ} \mathrm{C}$. Furthermore, it was found that the increased variation in 
Table 3. Comparison of statistical parameters for developed regression models

\begin{tabular}{lccccc}
\hline Regression model & $R^{2}$ & $P$ & SEE & DF & AIC \\
\hline Temperature & & & & & \\
$\quad F_{\mathrm{c}}=-3.93+0.70 T_{\mathrm{s}}$ & 0.33 & $<0.01$ & 5.06 & 58 & 368.83 \\
$F_{\mathrm{c}}=0.75 \times \mathrm{e}^{0.12 T_{\mathrm{s}}}$ & 0.40 & $<0.01$ & 0.72 & 58 & 135.59 \\
$\quad F_{\mathrm{c}}=3.17 \times 3.25^{\left(T_{\mathrm{s}-10 / 10)}\right.}$ & 0.31 & $<0.01$ & 5.10 & 59 & 367.90 \\
Moisture & & & & & \\
$\quad F_{\mathrm{c}}=-3.59+0.47 S_{\mathrm{m}}$ & 0.21 & $<0.01$ & 5.47 & 58 & 378.08 \\
$\quad F_{\mathrm{c}}=-10.65+1.14 S_{\mathrm{m}}-0.01 S_{\mathrm{m}}^{2}$ & 0.23 & $<0.01$ & 5.46 & 57 & 378.90 \\
Combined effect & & & & & \\
$\quad F_{\mathrm{c}}=-15.28+0.49 S_{\mathrm{m}}+0.73 T_{\mathrm{s}}$ & 0.56 & $<0.01$ & 4.11 & 57 & 344.76 \\
$F_{\mathrm{c}}=3.07 \times 3.37^{\left(T_{\mathrm{s}-10 / 10)}\right.} \times\left(-1.53+0.16 S_{\mathrm{m}}-0.001 S_{\mathrm{m}}^{2}\right)$ & 0.66 & $<0.01$ & 3.64 & 58 & 332.58 \\
\hline
\end{tabular}

$F_{\mathrm{c}}$, Soil $\mathrm{CO}_{2}$ efflux rate; $T_{\mathrm{s}}$, Soil temperature; $S_{\mathrm{m}}$, Soil moisture; $R^{2}$, Coefficient of determination; $P$, Significance level; SEE, Standard error; DF, Degree of freedom; AIC, Akaike's information criteria.
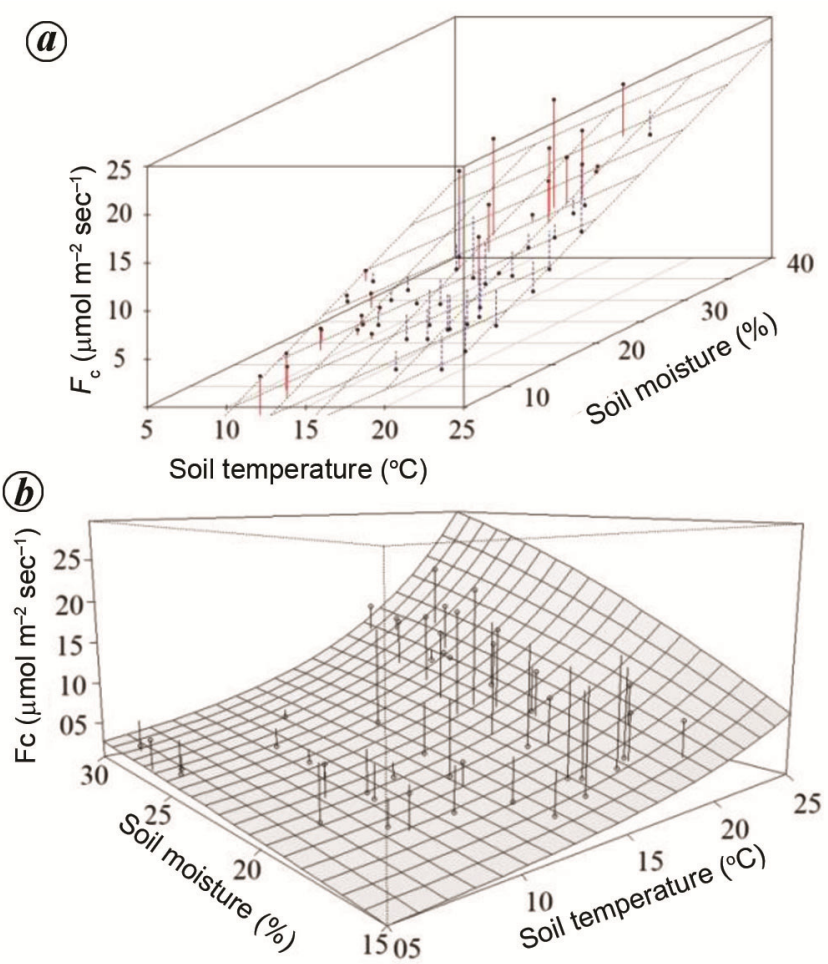

Figure 5. Three-dimensional scatter plot of soil temperature $\left(T_{\mathrm{s}}\right)$, soil moisture $\left(S_{\mathrm{m}}\right)$ and soil $\mathrm{CO}_{2}$ efflux $\left(F_{\mathrm{c}}\right)$. $\boldsymbol{a}$, Linear model; $\boldsymbol{b}$, Non-linear model.

$F_{\mathrm{c}}$ above $15^{\circ} \mathrm{C}$ temperature was influenced by soil moisture content. The relationship between $F_{\mathrm{c}}$ and soil moisture varied significantly with temperature regime as $R^{2}$ of 0.48 and 0.05 for above and below $15^{\circ} \mathrm{C}$ respectively (Figure $7 a$ and $b$ ).

\section{Discussion}

\section{Average soil $\mathrm{CO}_{2}$ efflux rates}

The in situ measurement of $F_{\mathrm{c}}$ allows us to observe the combined effect of autotrophic respiration from plant and heterotrophic respiration from microbes decomposing soil organic matter in natural condition ${ }^{33}$. The $F_{\mathrm{c}}$ measured during the study period ranged from $1.58 \pm 0.20$ to $17.60 \pm 1.68 \mu \mathrm{mol} \mathrm{m}^{-2} \mathrm{sec}^{-1}$ which was within the range for temperate forests reported in previous studies ${ }^{34,35}$. Soil $\mathrm{CO}_{2}$ efflux rate in temperate forest was reported in the range of 0.02 to $25.35 \mu \mathrm{mol} \mathrm{m} \mathrm{sec}^{-1}$ whereas, for temperate grassland it was reported in the range of 4 to $18 \mu \mathrm{mol} \mathrm{m} \mathrm{sec}^{-1}$ (refs 34, 35). The high $\mathrm{CO}_{2}$ efflux in the study area may be attributed to high carbon content ${ }^{34}$.

\section{Temporal and spatial pattern of soil $\mathrm{CO}_{2}$ efflux}

The soil temperature has an influence on litter decomposition and root respiration whereas, soil moisture affects the microbial community by influencing substrate availability and oxygen exchange in soil ${ }^{19,20}$. The study showed that there was significant temporal and spatial variation in $F_{\mathrm{c}}$. The $F_{\mathrm{c}}$ started increasing with the onset of summer and was high $\left(17.6 \mu \mathrm{mol} \mathrm{m} \mathrm{mec}^{-1}\right)$ during rainy season which coincided with high soil temperature and soil moisture (i.e. $21^{\circ} \mathrm{C}$ and $31.7 \%$ ). With decrease in temperature during winters, $F_{\mathrm{c}}$ also decreased and reached low in December when temperature was also lowest. This indicated that soil temperature was the main controlling factor of soil microbial activity and respiration resulting in soil $\mathrm{CO}_{2}$ efflux rate ${ }^{36}$. The $F_{\mathrm{c}}$ varied seasonally as well as with altitudinal variations and the annual $F_{\mathrm{c}}$ was observed maximum at $1800 \mathrm{~m}$ amsl. It might be due to the difference in nutrient content at different elevation levels as evident from high phosphorus and potassium at $1800 \mathrm{~m}$ elevation compared to other two elevations. Since, the source of soil $\mathrm{CO}_{2}$ efflux is predominantly a soil microbial activity, any change in biotic and abiotic factors influencing this activity would result in a change of soil $\mathrm{CO}_{2}$ efflux. The results showed that the annual $\mathrm{CO}_{2}$ efflux was more at east-facing slope than south and north-facing slope. It might be due to the higher availability of solar radiation at east-facing slope which 
was responsible for higher temperature than the other aspects, which was favourable for microbial growth and resulted in high annual $F_{\mathrm{c}}$. The soil and micro-climatic components vary with physiography which might be responsible for changes in $F_{\mathrm{c}}$ (refs 15,16 ). In recent past, studies have shown the effect of micro-climatic parameters on soil $\mathrm{CO}_{2}$ efflux along spatial variations ${ }^{17,37}$. Some studies reported that $F_{\mathrm{c}}$ decreased with increase in elevation $^{38}$ whereas, some reported its rise with elevation ${ }^{39}$. However, the results of the present study are not in direct conformity with the previous findings as it did not deal with linear relationship with elevation. These diverse results could be due to varying nutrient content and micro-climatic parameters such as soil temperature, soil moisture at different elevation levels which are directly responsible for the growth of soil microbes and thus explain the variations in $F_{\mathrm{c}}$ along different elevations as observed in this study.

\section{Controlling factors}

The present study showed that soil temperature, soil moisture and evaporation are the principle limiting factors with $R^{2}$ value of 0.85 at significance level of 0.05 , which controls the soil biochemical processes and soil
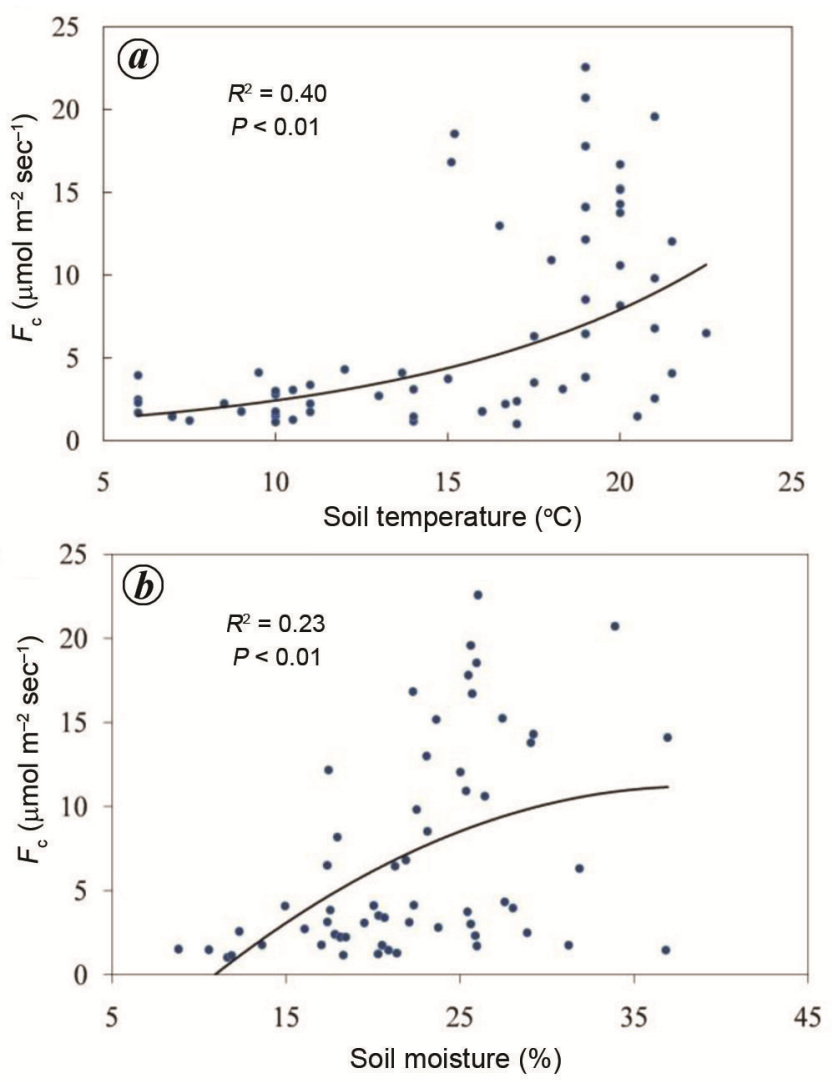

Figure 6. Relationship between (a) soil $\mathrm{CO}_{2}$ efflux and soil temperature, $(\boldsymbol{b})$ soil $\mathrm{CO}_{2}$ efflux and soil moisture $(0-30 \mathrm{~cm})$.
$\mathrm{CO}_{2}$ efflux (eq. (11)). The main influencing factors, i.e. soil temperature and soil moisture, control most of the soil processes affecting microbial activities. Soil moisture and soil temperature have been reported as the major controlling factors that manipulate soil $\mathrm{CO}_{2}$ emissions ${ }^{10,36}$. In the rainy season both the factors were favourable for microbial growth which triggered $\mathrm{CO}_{2}$ emissions while during winters, the temperature was very low resulting in low $F_{\mathrm{c}}$. The heterogeneous distribution of $F_{\mathrm{c}}$ can be suitably explained by soil temperature and soil moisture content $^{40,41}$.

The effect of soil temperature was best explained by exponential model. This might be due to the exponential growth of microbes as the temperature increases. The effect of soil moisture was explained by the quadratic model. The findings were in conformity with the previous studies $^{22}$. The combined effect of soil temperature and soil moisture was better explained by non-linear model with higher $R^{2}$ value as reported by previous studies ${ }^{22,42}$.

The temperature sensitivity factor $\left(Q_{10}\right)$ which represents degree of dependence of soil $\mathrm{CO}_{2}$ efflux on soil temperature was 3.25 for the study area, and it was within the range of other reported $Q_{10}$ values for natural forest ${ }^{43,44}$. It
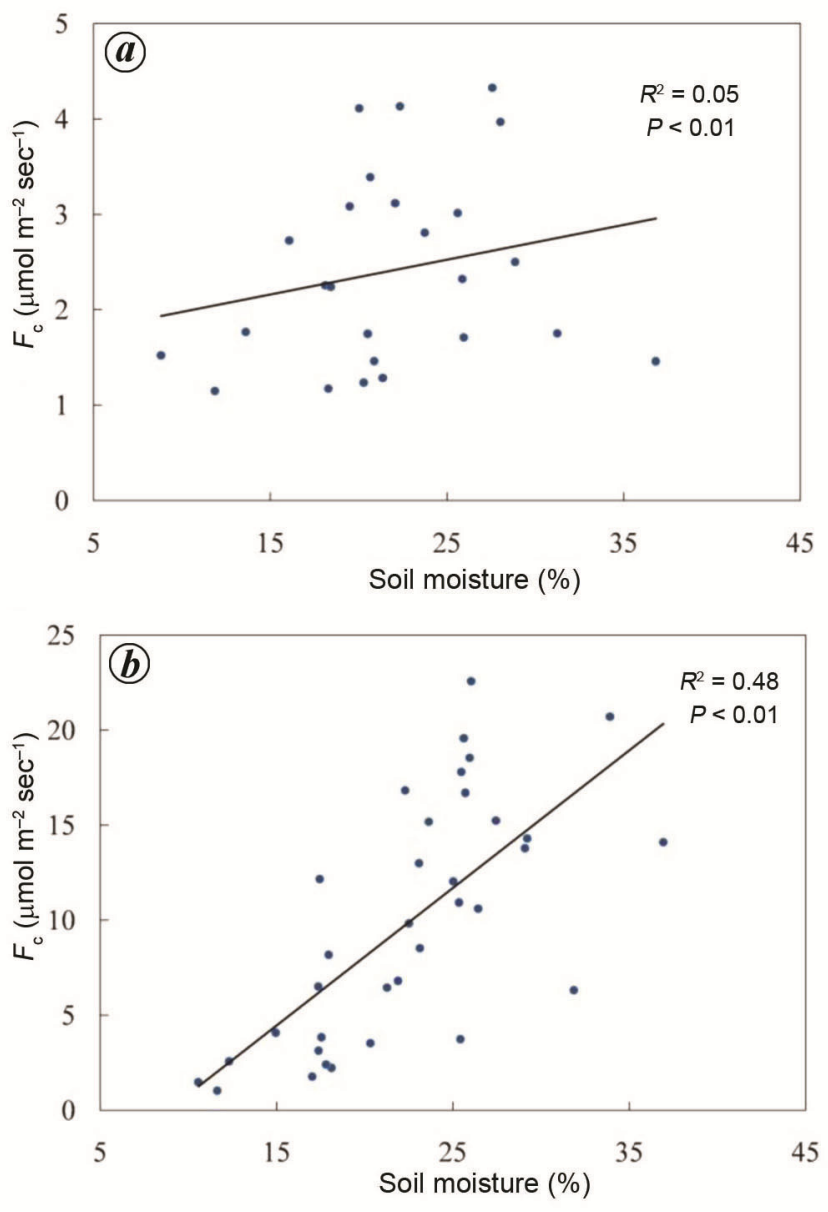

Figure 7. Relationship between soil $\mathrm{CO}_{2}$ efflux $F_{\mathrm{c}}\left(\mu \mathrm{mol} \mathrm{m} \mathrm{m}^{-2} \mathrm{sec}^{-1}\right)$ and soil moisture (\%): $\boldsymbol{a}$, soil temperature $\left(T_{\mathrm{s}}\right)<15^{\circ} \mathrm{C} ; \boldsymbol{b}, T_{\mathrm{s}} \geq 15^{\circ} \mathrm{C}$. 


\section{RESEARCH ARTICLES}

was found that influence of soil moisture was negligible when soil temperature was below $15^{\circ} \mathrm{C}$, whereas its effect on $F_{\mathrm{c}}$ above $15^{\circ} \mathrm{C}$ exhibited better relationship with $R^{2}$ value of 0.48 . The $F_{\mathrm{c}}$ was not sensitive to temperature under low moisture $(<7.5 \%)$, but was more responsive to temperature under high moisture content $(10 \%-25 \%)^{45}$. Moreover, the soil microbes need optimum moisture level whereas too high or too low moisture can limit soil $\mathrm{CO}_{2}$ efflux rate. Furthermore, high soil moisture content limits aeration and low level leads to desiccation and reduced substrate supply, which restricts microbial metabolism ${ }^{46}$. Therefore, the present study explains the importance of both soil temperature and soil moisture as controlling factors of soil $\mathrm{CO}_{2}$ emissions ${ }^{10}$. In addition, increasing temperature and erratic rainfall pattern due to global warming and climate change could significantly affect the soil carbon storage of the moist temperate forest ecosystem of West Himalayas.

\section{Conclusion}

It is concluded that the $\mathrm{CO}_{2}$ efflux rate is significantly influenced by seasonal changes and physiography (elevation and aspect) of the study area including various soil factors such as temperature, moisture and nutrients conditions. Summer and rainy season, being most favourable for microbial growth, displayed maximum $F_{\mathrm{c}}$ values. The east-facing slope by virtue of receiving more solar radiation than the other directional aspects, showed higher $F_{\mathrm{c}}$. In addition, the effect of soil temperature and soil moisture was better explained by non-linear models compared to traditional linear models. Further, it was established that the soil temperature and soil moisture are both needed at an optimum level for microbial growth below which the soil $\mathrm{CO}_{2}$ emissions range was limited. Therefore, stored soil carbon of moist temperate forests of West Himalayas is sensitive to global warming and changing climatic conditions. Moreover, long-term monitoring of soil $\mathrm{CO}_{2}$ efflux along with soil nutrient changes such as organic carbon, nitrogen, phosphorus, and potassium, etc. and micro-climatic parameters are needed to enhance the understanding of soil carbon dynamics and contribution of soil processes to atmospheric $\mathrm{CO}_{2}$.

1. Scharlemann, J. P. W., Tanner, E. V. J., Hiederer, R. and Kapos, V., Global soil carbon: understanding and managing the largest terrestrial carbon pool. Carbon Manag., 2014, 5, 81-91.

2. Van Groenigen, K. J., Xia, J., Osenberg, C. W., Luo, Y. and Hungate, B. A., Application of a two-pool model to soil carbon dynamics under elevated $\mathrm{CO}_{2}$. Glob. Chang. Biol., 2015, 21, 4293-4297.

3. Davidson, E. A. and Janssens, I. A., Temperature sensitivity of soil carbon decomposition and feedbacks to climate change. Nature, 2006, 440, 165-173.

4. Ballantyne, A. P. et al., Audit of the global carbon budget: estimate errors and their impact on uptake uncertainty. Biogeosciences, 2015, 12, 2565-2584.
5. Seneviratne, S. I. et al., Investigating soil moisture-climate interactions in a changing climate: a review. Earth Sci. Rev., 2010, 99, 125-161.

6. Wu, Z., Dijkstra, P., Koch, G. W., Peñuelas, J. and Hungate, B. A., Responses of terrestrial ecosystems to temperature and precipitation change: a meta-analysis of experimental manipulation. Glob. Chang. Biol., 2011, 17, 927-942.

7. FSI, India State of Forest Report, 2017.

8. Tewari, V. P., Verma, R. K. and von Gadow, K., Climate change effects in the Western Himalayan ecosystems of India: evidence and strategies. Forest Ecosyst., 2017, 4, 1-9.

9. Baldocchi, D., Tang, J. and Xu, L., How switches and lags in biophysical regulators affect spatial-temporal variation of soil respiration in an oak-grass savanna. J. Geophys. Res. Biogeosci., 2006, 111, 1-13.

10. Davidson, E. A., Belk, E. and Boone, R. D., Soil water content and temperature as independent or confounded factors controlling soil respiration in a temperate mixed hardwood forest. Glob. Chang. Biol., 1998, 4, 217-227.

11. Raich, J. and Schlesinger, W., The global carbon dioxide flux in soil respiration. Tellus B, 1992, 44, 81-99.

12. Moser, G., Leuschner, C., Hertel, D., Graefe, S., Soethe, N. and Iost, S., Elevation effects on the carbon budget of tropical mountain forests (S Ecuador): the role of the below ground compartment. Glob. Chang. Biol., 2011, 17, 22112226.

13. Raich, J. W., Russell, A. E., Parton, W. J. and Vitousek, P. M., Temperature influences carbon accumulation in moist tropical forests. Ecology, 2006, 87, 76-87.

14. Hanson, P. J., Edwards, N. T., Garten, C. T. and Andrews, J. A., Separating root and soil microbial contributions to soil respiration: a review of methods and observations. Biogeochemistry, 2000, 48, $115-146$.

15. Grand, S., Rubin, A., Verrecchia, E. P. and Vittoz, P., Variation in soil respiration across soil and vegetation types in an Alpine valley. PLOS ONE, 2016, 11, 1-16.

16. La Scala, N., Marques, J., Pereira, G. T. and Corá, J. E., Carbon dioxide emission related to chemical properties of a tropical bare soil. Soil Biol. Biochem., 2000, 32, 1469-1473.

17. Rayment, M. B. and Jarvis, P. G., Temporal and spatial variation of soil $\mathrm{CO}_{2}$ efflux in a Canadian boreal forest. Soil Biol. Biochem., $2000,32,35-45$.

18. Hursh, A., Ballantyne, A., Cooper, L., Maneta, M., Kimball, J. and Watts, J., The sensitivity of soil respiration to soil temperature, moisture, and carbon supply at the global scale. Glob. Chang. Biol., 2017, 23, 2090-2103.

19. Ruehr, N. K., Knohl, A. and Buchmann, N., Environmental variables controlling soil respiration on diurnal, seasonal and annual time-scales in a mixed mountain forest in Switzerland. Biogeochemistry, 2010, 98, 153-170.

20. Ryan, M. G. and Law, B. E., Interpreting, measuring, and modeling soil respiration. Biogeochemistry, 2005, 73, 3-27.

21. Jassal, R. S., Black, T. A., Novak, M. D., Gaumont-guay, D. and Nesic, Z., Effect of soil water stress on soil respiration and its temperature sensitivity in an 18-year-old temperate Douglas-fir stand. Glob. Chang. Biol., 2008, 14, 1305-1318.

22. Zimmermann, M., Davies, K., Peña De Zimmermann, V. T. V. and Bird, M. I., Impact of temperature and moisture on heterotrophic soil respiration along a moist tropical forest gradient in Australia. Soil Res., 2015, 53, 286-297.

23. Conant, R. T. et al., Temperature and soil organic matter decomposition rates - synthesis of current knowledge and a way forward. Glob. Chang. Biol., 2011, 17, 3392-3404.

24. IPCC, Climate Change 2014: Mitigation of Climate Change Working Group III Contribution to the Fifth Assessment Report of the Intergovernmental Panel on Climate Change Cambridge University Press, 2014. 
25. Luo, Y., Wan, S., Hui, D. and Wallace, L. L., Acclimatization of soil respiration to warming in a tall grass prairie. Nature, 2001, 413, 622-625.

26. Roy, P. S., Kushwaha, S., Murthy, M. and Roy, A., Biodiversity Characterisation at Landscape Level: National Assessment, Indian Institute of Remote Sensing, Indian Space Research Organisation, Government of India, Dehradun, 2012.

27. Mathews, G., The carbon content of trees. Forestry Commission Technical Paper 4. Forest Comm., 1993.

28. Rochette, P. et al., Description of a dynamic closed chamber for measuring soil respiration and its comparison with other techniques. Can. J. Soil Sci., 1997, 77, 195-203.

29. Madsen, R., Liukang, X. and Dayle, M., Considerations for making chamber-based soil $\mathrm{CO}_{2}$ flux measurements. In 19th World Congress of Soil Science: Soil Solutions for a Changing World, Brisbane, Australia, 1-6 August 2010, Congress Symposium 4: Greenhouse Gases from Soils. 2010, pp. 28-31.

30. Reichstein, M. et al., On the separation of net ecosystem exchange into assimilation and ecosystem respiration: review and improved algorithm. Glob. Chang. Biol., 2005, 11, 1424-1439.

31. Fox, J., Using the R Commander: A Point-and-Click Interface for $R$, CRC Press, USA, 2016, vol. 75, pp. 1-219.

32. Burnham, K. P. and Anderson, D. R., Multimodel inference: understanding AIC and BIC in model selection. Sociol. Methods Res., 2004, 33, 261-304.

33. Bond-Lamberty, B. and Thomson, A., Temperature-associated increases in the global soil respiration record. Nature, 2010, 464, 579-582.

34. Lecki, N. A. and Creed, I. F., Forest soil $\mathrm{CO}_{2}$ efflux models improved by incorporating topographic controls on carbon content and sorption capacity of soils. Biogeochemistry, 2016, 129, $307-$ 323 .

35. Joos, O. et al., Summer drought reduces total and litter-derived soil $\mathrm{CO}_{2}$ effluxes. Biogeosciences, 2010, 7, 1031-1041.

36. Taylor, A. J. et al., Radiocarbon-based partitioning of soil respiration in an old-growth coniferous forest. Ecosystems, 2015, 18, 459-470.

37. Zimmermann, M., Meir, P., Bird, M. I., Malhi, Y. and Ccahuana, A. J. Q., Temporal variation and climate dependence of soil respiration and its components along a $3000 \mathrm{~m}$ altitudinal tropical forest gradient. Global Biogeochem. Cycles, 2010, 24, 1-13.
38. Shi, Z. et al., Soil respiration and its regulating factor along an elevation gradient in Wuyi Mountain of Southeast China. Chinese J. Ecol., 2008, 27, 562-568.

39. Wu, Y. Q., Liu, G. H., Fu, B. J., Guo, Y. H. and Hu, C. J., Soil $\mathrm{CO}_{2}$ emission distribution along an elevation gradient and the controlling factors in the forest ecosystem. Acta Ecol. Sin., 2007, 27, 4678-4685.

40. Shi, B. and Jin, G., Variability of soil respiration at different spatial scales in temperate forests. Biol. Fertil. Soils, 2016, 52, 561-571.

41. Kang, S., Doh, S., Lee, D., Lee, D., Jin, V. L. and Kimball, J. S., Topographic and climatic controls on soil respiration in six temperate mixed-hardwood frest slopes, Korea. Glob. Chang. Biol., 2003, 9, 1427-1437.

42. Qi, Y. and $\mathrm{Xu}, \mathrm{M}$., Separating the effects of moisture and temperature on soil $\mathrm{CO}_{2}$ efflux in a coniferous forest in the Sierra Nevada mountains. Plant Soil, 2001, 237, 15-23.

43. Chen, Y., Luo, J., Li, W., Yu, D. and She, J., Comparison of soil respiration among three different subalpine ecosystems on eastern Tibetan Plateau, China. Soil Sci. Plant Nutr., 2014, 60, 231-241.

44. Saiz, G., Black, K., Reidy, B., Lopez, S. and Farrell, E. P., Assessment of soil $\mathrm{CO}_{2}$ efflux and its components using a processbased model in a young temperate forest site. Geoderma, 2007, 139, 79-89.

45. Carlyle, J. C. and Than, U. B., Abiotic controls of soil respiration beneath an eighteen-year-old pinus radiata stand in south-eastern Australia. J. Ecol., 1988, 76, 654-662.

46. Rey, A., Pegoraro, E., Tedeschi, V., De Parri, I., Jarvis, P. G. and Valentini, R., Annual variation in soil respiration and its components in a coppice oak forest in Central Italy. Glob. Chang. Biol., 2002, 8, 851-866.

ACKNOWLEDGEMENTS. We thank the Forest Research Institute, Dehradun for being part of the research project, 'Assessment of hydrological services imparted by forest of Kempty watershed (Mussoorie)' and Indian Council of Forestry Research and Education for funding the study.

Received 7 April 2019; revised accepted 13 February 2020

doi: $10.18520 / \mathrm{cs} / \mathrm{v} 119 / \mathrm{i} 4 / 661-669$ 